原著

同時性食道胃重複癌症例の診断と治療の問題点

\begin{tabular}{cccccr}
\multicolumn{5}{c}{ 横浜市立大学第 1 外科 } \\
今田 & 敏夫 & 安部 & 雅夫 & 野口 & 芳一 \\
青山 & 法夫 & 山本 & 裕司 & 田村 & 聡 \\
赤池 & 信 & 天野 & 富薫 & 松本 & 昭彦 \\
& \multicolumn{3}{c}{ 神奈川県立がんセンター外科 } & \\
小 & 泉 & 博 & 義 &
\end{tabular}

\title{
DIAGNOSIS AND SURGICAL TREATMENT FOR MULTIPLE PRIMARY CANCER OF THE ESOPHAGUS AND THE STOMACH
}

\author{
Toshio IMADA, Masao ABE, Yoshikazu NOGUCHI \\ Norio AOYAMA, Yuji YAMAMOTO, Satoshi TAMURA, \\ Makoto AKAIKE, Tomishige AMANO, Akihiko MATSUMOTO \\ and Hiroyoshi KOIZUMI*
}

The First Department of Surgery, Yokohama City University School of Medicine *Department of Surgery, Kanagawa Cancer Center

同時性に発生した食道胃重複癌切除症例 7 例を対象とし, その診断, 手術および治療成績について 検討した。

術前に 7 例中 5 例が食道, 胃病変ともに正しく診断されたが, 特に鑑別診断上重要と思われたのは 食道癌の胃壁内転移であった。

手術々式はリンパ節郭清を考虑し, 胸部食道病変に対しては胸部食道全摘が, 胃病変に対しては病 巣が $\mathrm{A}$ または M に存在する場合, あるいは C K存在し進行癌と考兄られる場合には胃全摘術が, C に 存在し早期癌之考えられる場合には噴門側切除が行われた。しかし, 治療成績は不良で 7 例中 5 例が 術後 1 年以内に死亡した。 また， 2 例が術後肺合併症で死亡した点から手術適応の決定は慎重にすべ きと思われた。

索引用語：同時性食道胃重複癌, 食道癌, 胃癌, 食道癌胃壁内転移

はじめに

近年, 重複癌は診断技術预よび治療成績の向上にと むなって, その報告例12) も増加して来た。 その中でる 食道胃重複癌は診断（とくに胃病変の存在診断, 質的 診断) ならびに外科治療（手術々式，リンパ節郭清, 再建臓器なと゚）に関し多くの問題を含んでいる，そこ で, 同時性食道胃重複癌切除症例を対象とし, 診断, 臨床病理学的所見, 手術, 治療成績について検討した

$<1988$ 年 1 月13日受理 >別刷請求先：今田 敏夫 干232 横浜市南区浦舟町 3-46 横浜市立大学医学 部第 1 外科
ので報告する。

\section{対象}

1976年から1985年までの10年間に経験した同時性食 道胃重複癌症例は12例で, 切除 7 例, 非切除 5 例であっ た。切除症例のみでみると同期間の胸部食道癌111例の $6.3 \%$ ，胃癌398例の $1.7 \%$ 占めた（表 1 ）。な抏，臨 床病理学的所見は食道癌取扱(規約 ${ }^{3}$, 胃癌取扱い規 約)に従った。

\section{成 績}

（1）年齢，性，主訴，病悩期間

切除例の年龄は55歳から77歳 (平均64.9歳) で, 性 
表 1 同時性食道胃重複癌の臨床的特徵

\begin{tabular}{|c|c|c|c|c|c|}
\hline & 应做数 & 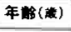 & 性比 $(\delta / q)$ & 主 & 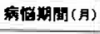 \\
\hline 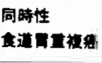 & 7 湖 & 64.9 & $6.0 / 1$ & $\begin{array}{c}\text { 蓦下困素 } \\
(4 / 7)\end{array}$ & $2.7(1 \sim 5)$ \\
\hline 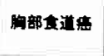 & 111例 & 62.9 & $5.9 / 1$ & $\begin{array}{c}\text { C下困㭗 } \\
(90 \%)\end{array}$ & $4.6(1 \sim 16)$ \\
\hline 问 & 398例 & 57.3 & $1.7 / 1$ & $\begin{array}{c}\text { 心雷部浠 } \\
(60 \%)\end{array}$ & $6.4(1 \sim 72)$ \\
\hline
\end{tabular}

表 2 同時性食道胃重複癌 (切除例)

\begin{tabular}{|c|c|c|c|c|c|c|c|c|c|c|}
\hline \multirow{2}{*}{ 症倒 } & \multirow{2}{*}{ 年卙 } & \multirow{2}{*}{ 性 } & \multicolumn{4}{|c|}{ 金道病变 } & \multicolumn{4}{|c|}{ 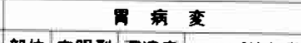 } \\
\hline & & & 部位 & 肉眼型 & 深達度 & リンパ触枟移 & 部位 & 由眼型 & 架䢖度 & リンパ筒転移 \\
\hline (1) & 72 & $\hat{\sigma}$ & Ei $\sim \operatorname{Im}$ & 淀籍 & $a_{2}$ & $\mathrm{n}_{2}$ & C & Borr 3 & se & $n_{2}$ \\
\hline (2) & 63 & $\hat{\sigma}$ & Im & 清事 & $a_{2}$ & $n_{3}$ & $\underset{A}{M}$ & \begin{tabular}{|} 
II c \\
Borr. 2
\end{tabular} & $\begin{array}{l}\text { sm } \\
\text { se }\end{array}$ & $n$, \\
\hline (3) & 49 & 우 & Im & 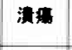 & $m p$ & $n(-)$ & A & II a & $m$ & $\begin{array}{c}\mathrm{nx} \\
\text { (ポリでクトミー) }\end{array}$ \\
\hline (4) & 67 & $\widehat{\delta}$ & Im & 表㾍 & $\mathrm{sm}$ & $n(-)$ & $\begin{array}{l}M \\
M \\
M \\
A\end{array}$ & $\begin{array}{l}\text { II c } \\
\text { II } \\
\text { II }\end{array}$ & $\begin{array}{l}\mathrm{m} \\
\mathrm{m} \\
\mathrm{sm}\end{array}$ & $\mathrm{n}_{0}$ \\
\hline (5) & 77 & $\hat{\delta}$ & Ei & 表屈 & $\mathrm{sm}$ & $\pi x$ & $\mathrm{C}$ & II a & $\mathrm{sm}$ & $n(-)$ \\
\hline (6) & 71 & $\hat{\sigma}$ & $\mathrm{Ei} \sim \mathrm{Ea}$ & 表層 & $\mathrm{sm}$ & $n(-)$ & C & Borr 3 & se & $n_{2}$ \\
\hline$*(7)$ & 55 & $\delta$ & $\begin{array}{l}\mathrm{Ce} \\
\mathrm{Ei}\end{array}$ & 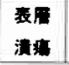 & $\begin{array}{r}\mathrm{sm} \\
\mathrm{a}_{2}\end{array}$ & $\mathrm{n}_{2}$ & CM & II c進 & se & $n_{1}$ \\
\hline
\end{tabular}

別は男性 6 例，女性 1 例と男性が多かった．主訴は暖 下困難が 4 例と多く, 他は食思不振, 体重减少, 嗄声 などで，食道癌による症状が主であった，病悩期間は 1 か月から 5 か月(平均 2.7 月)と短期間であった(表 $1)$.

(2) 診断

術前に食道病変, 胃病変ともに正診が得られたのは 5 例で, 症例 1 は食道病変のみが診断され, 胃病変は 術中に気付いた症例である。 また，症例 4 は食道病変 と 1 個の胃病変が術前に診断され手術が行われたが, 術後の病理組織学的検索により, さらに 2 個の微小早 期胃癌が明らかとなった症例である（表 2).

(3) 臨床病理学的所見

(a) 占居部位

食道病変の占居部位は $\mathrm{Im} 3$ 例, $\mathrm{Ei} 3$ 例, $\mathrm{Ce} \cdot \mathrm{Ei}$ の 重複 1 例と中部, 下部に多く, 胃病変は C 4 例, M. A の重複 2 例, A 1 例と胃上部に多い傾向がみられた (表 2).

(b) 肉眼型

食道病変 7 例 8 病巣の肉眼型は漬瘍型 4 病巣, 表層 型 4 病巣で, 胃病変 7 例10病栄のそれは IIc 型早期癌 4 病栄, IIa 型早期癌 2 病巣, Borrmann 2 型 1 病巣,
Borrmann 3 型 2 病巣, IIc 進行型 1 病変と胃病変に早 期癌が多いことが特徵であった（表 2).

(C) 深達度とリンパ節転移

症例 $1,2,7$ は食道病変, 胃病変ともに進行癌で, いずれもリンパ節転移陽性であった。症例 3 は食道病 変に対し術前放射線治療が行われた結果, 深達度は R-mpでリンパ節転移は陰性であった。胃病変は隆起 性病変でポリペクトミーを施行し,その深達度は mで あった。症例 6 は食道病変が $\mathrm{sm}, \mathrm{n}($ 一) と早期癌で あったが, 胃病変はse, $\mathrm{n}_{2}$ と進行癌であった。症例 4 , 5 は食道病変, 胃病変ともに $\mathrm{sm}$ にとどまる早期の病 変であった（表 2 ）。

(4) 手術々式

症例 3 は食道病変に対し照射を行ったが，その他の 症例はいずれも一期的に切除, 再建術が行われた。胸 部食道病変に対する術式は胸部食道全摘と一定してお ク, 主として胃病変の占居部位と進行度により術式が 決定されている. 胃病変が A, M に存在する症例 2 ， 4 とCに存在するが進行癌であった症例 6 に対して は胃全摘が施行された。胃病変が $\mathrm{C}, \mathrm{CM}$ に存在し術 前, 比較的早期と診断した（実際には術後の病理組織 学的検索で進行癌であった例もあるが) 症例 1，5， 7 は噴門側切除が行われた。 な㧍, 症例 3 は隆起性病 变でポリペクトミーが行われた。

再建方法は切除範囲に上り決定され，胃全摘が施行 された 3 例（症例 $2 ， 4 ， 6$ ）は結腸を, 他の 4 例は 亜全胃を用いた（表 3 ).

（5）治療成績

治恣切除が行われたのは 3 例のみで, 他の 4 例は非 治療切除に終った. 5 年以上の生存例は症例 3 の 1 例 のみで, 5 例は術後 1 年以内に死亡している. とくに 症例 6,7 は直死ではないが, 肺合併症のため院内死 亡した. 長期生存例である症例 3,5 は規約上 ${ }^{3 / 4)}$ は非 治瘾切除であるが，拔去術をした食道病変，ポリペク トミーをした胃病変ともに深達度が浅く、リンパ節郭 清していない部位にも転移が無かったと考えられる症 例である(表 3 ).

（6）早期癌の重複例

食道, 胃病変とも早期癌症例はまれなので, 症例 4 を詳しく述べる。

症例 : 67歳, 男性

主訴：食思不振（約 2 力月）

上部消化管造影所見: 胸部中部食道飞長径 $1.5 \mathrm{~cm}$ の表在隆起型の病変が存在し, 胃の幽門前庭部小弯に 
表 3 食道胃重複癌の手術々式と治療成績

\begin{tabular}{|c|c|c|c|c|c|c|}
\hline 症例 & 年数 & 性 & 手術々式 & 再建臟器 & 根治度 & 成 績 \\
\hline (1) & 72 & s & $\begin{array}{l}\text { 胸部食道全摘 } \\
\text { 胃嘪門部切除 }\end{array}$ & 胃 & 非治 & $\begin{array}{c}4 \text { か月 } \\
\text { (縱隔再発) }\end{array}$ \\
\hline (2) & 63 & $\hat{\delta}$ & $\begin{array}{l}\text { 胸部食道全摘 } \\
\text { 胃全摘 }\end{array}$ & 結腸 & 治 & $\begin{array}{l}8 \text { か月 } \\
\text { (不明) }\end{array}$ \\
\hline (3) & 49 & 우 & $\begin{array}{l}\text { 胸部食道全摘 } \\
\text { 胃ポリペクトミー }\end{array}$ & 胃 & 非治 & $\begin{array}{l}6 \text { 年 } \\
\text { (生) }\end{array}$ \\
\hline (4) & 67 & 今 & $\begin{array}{l}\text { 胸部食道全摘 } \\
\text { 胃全摘 }\end{array}$ & 結腸 & 治 & $\begin{array}{c}8 \text { か月 } \\
\text { (肝転移) }\end{array}$ \\
\hline (5) & 77 & $\hat{\delta}$ & $\begin{array}{l}\text { 食道抜去 } \\
\text { 胃噴門部切除 }\end{array}$ & 胃 & 非治 & $\begin{array}{c}3 \text { 年 } 7 \text { 月 } \\
\text { (生) }\end{array}$ \\
\hline (6) & 71 & $\hat{\delta}$ & $\begin{array}{l}\text { 胸部食道全摘 } \\
\text { 胃全摘 }\end{array}$ & 結腸 & 非治 & $\begin{array}{c}4 \text { か月 } \\
\text { (肺合併症) }\end{array}$ \\
\hline${ }^{*}(7)$ & 55 & $\hat{\delta}$ & $\begin{array}{l}\text { 喉頭食道全摘 } \\
\text { 胃喷門部切除 }\end{array}$ & 胃 & 治 & $\begin{array}{c}3 \text { か月 } \\
\text { (肺合併症) }\end{array}$ \\
\hline
\end{tabular}

図 1 症例 4 の食道 X 線所見. Im に境界明瞭な円形 の隆起性病変が認められる。

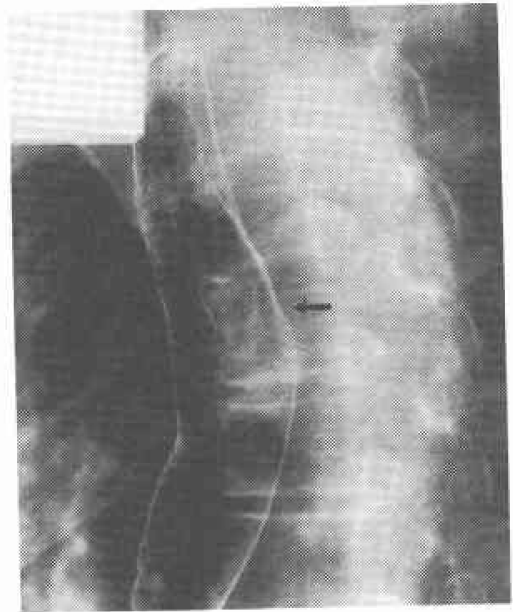

不整な二重陰影が認められた（図 1，2）.

内視鏡所見：門歯より $32 \mathrm{~cm}$ の部位に境界明瞭な表 在隆起型の病変が存在し、ルゴール染色にても不染带 として認められた。胃病変は幽門前庭部小弯に潰瘍性 病変が存在し, 周囲の fold の断裂が認められた. 以上 の所見から, 食道の表在隆起型の早期病変と胃の IIc十 III 型早期癌と診断し手術を施行した.

手術々式：右開胸, 開腹にて胸部食道全摘, 胃全摘 術施行し結腸で再建した。

病理組織学的所見：食道癌は表在隆起型で $\mathrm{sm}, \mathrm{n}$
図 2 症例 4 の胃 $\mathrm{X}$ 線所見. 胃前庭部小弯に不整形の 潰瘍があり，周囲に陷凹が認められる。

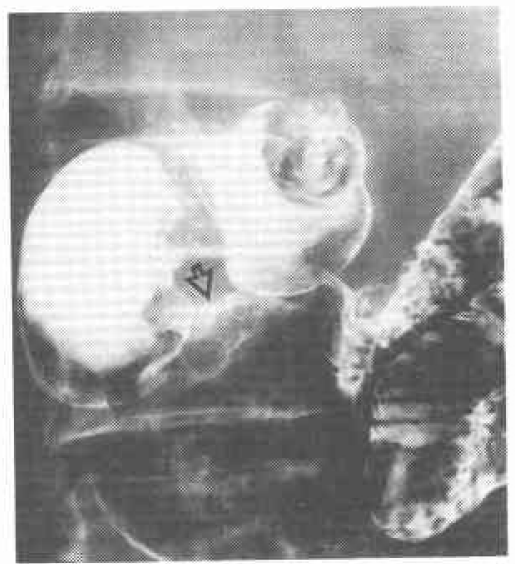

図 3 症例 4 の切除標本(食道). 白色を呈した表在隆 起型の病変が認められる.

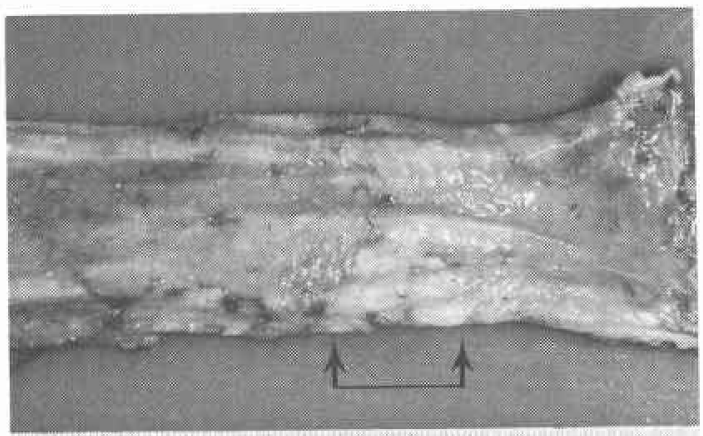

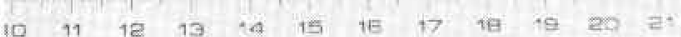

図 4 症例 4 の切除標本(胃). 幽門前庭部小弯やや前 壁側に中心に不整形の潰瘍を有する IIc + III 型早期 癌を認め，その口側に2 個の小楩凹性病変が認めら れる。

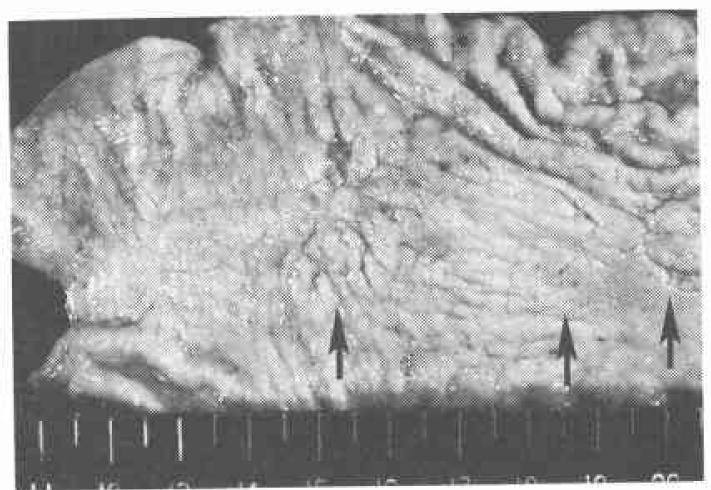


(一), 中分化型扁平上皮癌で, 胃癌は 3 病巣あり, IIc + III $(\mathrm{sm})$, IIc $(\mathrm{m})$, IIc $(\mathrm{m}), \mathrm{n}(-)$, 高分化型腺癌 で，いずれも早期癌であった（図 3，4）.

\section{考察}

現在, 重複癌の定義は, Warren \& Gates の定義6), すなわち（1）各腫瘍がそれぞれ一定の悪性像を示す こと，(2）明らかに区別されること，(3) お互いが 転移巣であることを否定できること，に従っている報 告が多いようである，食道の重複癌に関しては1977年 第23回日本食道疾患研究会でこのテーマがとりあげら れ，阿保5)によって集計され，かなり正確なデータを把 握することができた。 その発生頻度をみると同時性重 複癌症例は全食道癌症例の $2.1 \%$ 占め, 同時性食道胃 重複癌症例は $1.6 \%$ を占めている。われわれの症例は切 除例だけに限ったためか, この值よりも高率で食道癌 症例の6.3\%であった。

食道, 胃重複癌に抬いて問題となる点は第 1 に診断 である.術前診断の正確さにより,それに対する手術々 式もおのずと変ってくる，とくに食道病変の狭窄が高 度な症例においては, バリウムの通過不良により十分 に胃病変を描出することが不可能で，しかもファイ バースコープ通過不能の場合には詳細な胃病変の検索 は困難となってくる．幸い,われわれの症例はファイ バースコープの通過不能例が少なく，7例中 5 例が胃 病変を正しく診断することができた。この点に関して, 芦沢 ${ }^{7)}$ は手術時の視診, 触診, 迅速診断の重要性を述べ ており,内田8 ${ }^{8}$ は術中に胃切開創からファイバース コープを用いて詳細に検索していると述べている。こ の方法は胃病変の見逃しを少なくするために良い方法 だと思われる，胃に病変がある場合，鑑別診断上，之 くに重要なるのは食道癌の胃壁内転移巣9である。わ れわれの教室で同期間に経験した食道癌胃壁内転移切 除例は 7 例で表 4 に示した.

この症例から食道病変の特徵をみると, 比較的食道 下部に存在し, 肉眼型は潰瘍型で, リンパ節転移が高 度である。胃病変は全例 $\mathrm{C}$ 領域に存在し, その肉眼型 は粘膜下腫湯形態をとっている点が重複癌との鑑別診 断上重要なポイントである. 井手 ${ }^{10}$ 性原発性食道癌 813 例の病理組織学的検索を行い, $8.4 \%$ に壁内転移を認 め, とくに胃壁内転移巣は $5 \mathrm{~cm}$ 以上の大きさで壁全層 に及んでいると述べている。

診断が確定した後に問題となる点は手術々式,すな わち切除範囲と郭清範囲の選択であある。播種性転移 や血行性転移がない場合には, 癌の占居部位や進行度
表 4 食道癌胃内転移症例（切除例）

\begin{tabular}{|c|c|c|c|c|c|c|c|c|c|c|}
\hline \multirow{2}{*}{ 应何 } & \multirow{2}{*}{ 年䊝 } & \multirow{2}{*}{ 性 } & \multicolumn{5}{|c|}{ 道 病変 } & \multicolumn{3}{|c|}{ 異 病 变 } \\
\hline & & & 部位 & 肉眼型 & 深逢度 & 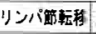 & 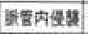 & 部位 & 肉眼型 & 深逢度 \\
\hline (1) & 67 & $\hat{\jmath}$ & lu & 謴雺 & $a_{2}$ & $n i-1$ & $(-)$ & c & Borr 2 & $\mathrm{~m} \sim \mathrm{se}$ \\
\hline (2) & 74 & $\hat{\sigma}$ & $E$ & 謴晹 & $a_{3}$ & $\begin{array}{l}\mathbf{n}_{2} \\
(\mathbb{1})\end{array}$ & (\#) & C & 炶㷛下㬴重 & sm $\sim$ se \\
\hline$|3|$ & 77 & 우 & $1 \mathrm{~m}$ & 謴腈 & $a_{1}$ & $\mathrm{n}_{4}$ & (H) & C & 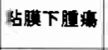 & sm \\
\hline (4) & 69 & $\hat{o}$ & $\lim \mathbf{E}$ & 溲神 & $a_{3}$ & $\mathrm{n}_{3}$ & (\#) & c & 粘集下啮武 & sm se \\
\hline$|5|$ & 54 & 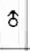 & Ea & 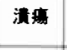 & $a_{z}$ & $\frac{n_{3}}{(\ln (1)(3)}$ & (\#) & c & 粘䀧下湴重 & m se \\
\hline (6) & 64 & 우 & $\mathrm{Im} \sim \mathrm{Ei}$ & 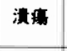 & $\mathbf{a}_{1}$ & $\begin{array}{c}\mathrm{n}_{2} \\
(\mathbf{n} \times(1) \cdot(2)\end{array}$ & $(-)$ & $\mathrm{C}$ & 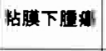 & sm se \\
\hline (7) & 55 & $\hat{\jmath}$ & $\mathrm{Ei} \sim \mathrm{Im}$ & 清蝫 & $a_{1}$ & $n(-)$ & $(+)$ & c & 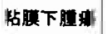 & sm se \\
\hline
\end{tabular}

表 5 胸部食道癌の部位別リンパ節転移率

\begin{tabular}{|c|c|c|c|c|c|c|c|c|c|c|c|c|c|c|c|}
\hline & 107 & 104 & 105 & 100 & 107 & 108 & 109 & 110 & 111 & 112 & 1 & 2 & 3 & 7 & 9 \\
\hline u & & & $1 / 4$ & $1 / 2$ & $0 / 2$ & $0 / 4$ & & $1 / 3$ & $0 / 1$ & $0 / 2$ & $0 / 17$ & $2 / 10$ & $2 / 5$ & $2 / 3$ & \\
\hline Im & $1 / 3$ & $1 / 4$ & $\begin{array}{r}6 / 19 \\
11.6 \\
\end{array}$ & $\begin{array}{r}5 / 12 \\
41\end{array}$ & $\begin{array}{l}8 / 24 \\
39: 1 \\
\end{array}$ & $\begin{array}{r}6 / 25 \\
(72) \\
\end{array}$ & $0 / 6$ & $\begin{array}{l}5 / 25 \\
2120 \\
\text { ind }\end{array}$ & $3 / 5$ & $2 / 6$ & $\begin{array}{l}21 / 98 \\
35,0\end{array}$ & $\begin{array}{l}16 / 39 \\
(4), 0\end{array}$ & $\begin{array}{r}0 / 34 \\
23.5 \\
\end{array}$ & $\begin{array}{l}3 / 23 \\
(11,04\end{array}$ & $1 / 2$ \\
\hline Ei) & & & Q/4 & $1 / 1$ & $1 / 4$ & $1 / 6$ & $1 / 2$ & $\begin{array}{l}3 / 11 \\
27.3\end{array}$ & $1 / 7$ & $7 / 5$ & $\begin{array}{l}10 / \mathrm{m} \\
45,5\end{array}$ & $\begin{array}{r}8 / 16 \\
50.02\end{array}$ & $\begin{array}{r}3 / 16 \\
(11.8\end{array}$ & $\begin{array}{l}3 / 7 \\
41\end{array}$ & 1/1 \\
\hline
\end{tabular}

表 6 胃癌の深達度とリンパ節転移（占居部位別） (C領域)

\begin{tabular}{|c|c|c|c|c|c|c|}
\hline & $n(-1)$ & $n_{1}$ & $\mathrm{n}_{2}$ & $n_{3}$ & $\mathrm{n}_{4}$ & tot \\
\hline$m$ & 1 & & & & & 1 \\
\hline $\mathrm{sm}$ & 7 & 2 & & & & 9 \\
\hline $\mathrm{pm}$ & 3 & 1 & & & & 4 \\
\hline $\mathrm{ss} \alpha \cdot \mathrm{ss} \beta$ & 2 & 2 & 2 & & & 6 \\
\hline s5 $\gamma$ & 2 & 0 & 2 & & & 4 \\
\hline se & 6 & 17 & 18 & 1 & 1 & 43 \\
\hline sei-sí & 1 & 4 & 3 & 0 & 2 & 10 \\
\hline 詁 & 22 & 26 & 25 & 1 & 3 & 77 \\
\hline
\end{tabular}

(M额域)

\begin{tabular}{l|c|c|c|c|c|c} 
& $n_{(-1}$ & $n_{1}$ & $n_{2}$ & $n_{3}$ & $n_{4}$ & $\frac{1}{1}$ \\
\hline $\mathrm{m}$ & 17 & & & & & 17 \\
\hline $\mathrm{sm}$ & 20 & 6 & 1 & & & 27 \\
\hline $\mathrm{pm}$ & 8 & 10 & 4 & & & 22 \\
\hline $\mathrm{ss} \alpha \cdot \mathrm{ss} \beta$ & 3 & 5 & 2 & & & 10 \\
\hline $\mathrm{ss} \gamma$ & 3 & 4 & 5 & & & 12 \\
\hline $\mathrm{se}$ & 7 & 10 & 23 & 5 & 1 & 46 \\
\hline $\mathrm{sei} \cdot \mathrm{si}$ & 1 & 1 & 2 & 1 & & 5 \\
\hline t+ & 59 & 36 & 37 & 6 & 1 & 139
\end{tabular}

によって左右され，それに加光，どの範囲までリンパ 節郭清をするかによって, おのずと切除範囲も決定さ れる。われわれは基本的には, 胸部食道癌に対しては 胸部食道全摘, 胃病変が $\mathrm{A}$ または $\mathrm{M}$ に存在する時に は胃全摘を行い, C に存在する場合には癌の進行度に 
よって異なり, 進行癌と診断した場合には胃全摘, 早 期癌と診断した場合には噴門側切除を行ってきた。こ の理論的根拠としているものは表 5,6 に示す教室の 単発の食道癌执よび胃癌の占居部位別リンパ節転移様 式である、このデータから見ると, 胸部食道癌のリン 八節転移は主病单の占居部位によって異なるが，腹腔 内人の転移率は高く,これに対する郭清は重要である。 胃癌の場合には $\mathrm{M}$ 領域のものは深達度 smからすで に第 2 群への転移が認められ，しかも大弯側領域にも 及んでいる.しかし，C領域のbのは深達度が pmにと どまるものは第 1 群すなわち No. 1，3 亿転移が見ら れるのみで，噴門側切除でも十分に郭清可能である. この手術々式の決定方法が正しいか否かは，症例が少 ない現時点で結論を出すことは不可能である。した がって，上記の適応にもとづいて症例を重ね再検討し なければならないと考学ている，この術式に対する考 方は報告者によって異っている。松原 ${ }^{11}$ は基本的に は食道, 胃全摘だが噴門部微小癌には噴門側切除でも 良いとしており，われわれの考方方に近い，一方，阿 保 ${ }^{12)}$ は胃周囲のリン八節郭清怯不十分となるが, 手術 侵襲が少なくてすむ利点を考兄胃を一部温存する術式 を採用している。われわれ非治癒切除に終る例には， なるべく胃を残す術式を採用している。

切除後の再建藏器は採用した切除術式によって決 まってくる、第23回日本食道疾患アンケートの結果で は小腸, 胃, 結腸の順である. われわれは贯全摘例に は結腸を，噴門側切除例には残胃を用いて再建してお り，小腸による再建の経験はない。

最後に治療成績についても考えてみたい. 病変の進 行度についてみると, 食道病変は進行している例が多 いが，逆に胃病変は早期癌であることが多いとの報 告7)1314)がある. しかし, 両病変とも早期の症例は非常 に少ないようである5).したがって, 食道癌のみでその 治療成績は不良であるのに加胃癌が重複する関係 上, その治療成績は非常に不良で, 阿保の報告5)では術 後 1 年以内に $72 \%$ が死亡している.

われわれの治療成績も同様で 7 例中 5 例 (71.4\%) が 1 年以内に死亡し, 5 年生存例は 1 例のみであった。 さらに, 2 例を術後肺合併症で失っていることはこの 手術に対する適応の困難さを示するのであり ${ }^{16)}$, 今後 細やかな検討を要する点である。 おわりに

横浜市立大学第 1 外科学教室で経験した食道胃重複 癌切除例 7 例を検討し，以下の結論を得た。
(1) 術前診断は 7 例中 5 例が正しく診断されたが, 食道癌の胃壁内転移例との鑑別が重要であった。

（2）手術々式は胃病変がCに存在し早期癌と診断 した場合には, 胸部食道全摘, 胃噴門部切除を施行し, 他は胸部食道全摘，胃全摘を施行した。

（3）治療成績は不良で 7 例中 5 例が 1 年以内に死亡 乙, 手術適応の決定は慎重にすべきと思われた。

\section{文献}

1）喜多みどり,大川智彦, 後藤真喜子ほか：食道に打 ける重複癌症例の検討. 臨放線 $29: 577-582$, 1984

2) 内田雄三, 森 義顥, 藤富 豊ほか：食道癌患者に みられた三重複癌の検討. 日癌治療会誌 $19: 543$ $-548,1984$

3）食道癌研究会編：食道癌取扱い規約. 改訂第 5 版. 金原出版, 東京, 1976

4) 胃癌研究会編：胃癌取扱い規約. 改訂第10版. 金原 出版, 東京, 1979

5）阿保七三郎, 三浦秀男, 工藤 保ほか：日本におけ る食道と他臓器重複癌について. 日消外会誌 13: 377-381, 1980

6) Warren S, Gates O: Multiple primary malig. nant tumors. A survey of the literature and a statistical study. Am J Cancer $16: 1358-1414$, 1932

7) 芦沢一喜, 森 昌造, 渡辺登志男ほか：食道と他臓 器との重複癌一とくに治療上の問題点について 一. 外科 $40: 627-631,1978$

8）内田雄三, 友成一英, 村上信一ほか：食道胃同時珄 重複癌に関する検討一とくに診断と外科治療上の 問題点について一. 日癌治療会誌 21：12921301, 1986

9) 前田廸郎, 西土井英明, 宮野陽介ほか：胸部食道癌 の胃壁内転移例. 手術 $31: 1217-1220,1977$

10）井手博子, 荻野知己, 吉田克己ほか：食道癌壁内転 移に関寸る臨床病理学的検討. 日消外会誌 13 ： $781-789,1980$

11）松原敏樹,中川 健, 陶 雅晴ほか：食道胃重複癌 の外科治療。消外 6:1247-1253, 1983

12）阿保七三郎, 工藤 保, 中村正明：胃に副病変を めった食道癌の外科治療一食道胃重複癌症例を中 心に一. 手術 38:893-901, 1984

13）奥平恭之, 池田正仁, 是永大輔䚾加：食道胃同時性 重複癌の外科治療一とくに早期胃癌との合併につ いて一。外科治療 $47: 128-131,1982$

14）泉 明夫, 西土井英昭, 金山博友ほか：食道己他臓 器の重複癌の検討. 外科 $43: 1019-1022,1981$

15）西 満正, 松原敏樹, 木下 峳ほか：リンパ節転移 から見た胸部食道癌の予後と再発形式. 消外 9 : 1597-1607, 1986

16）庭瀬公武, 稲岡正己, 高田憲一ほか：食道重複癌症 例の検討。癌の臨 $27: 1369-1372,1981$ 